\title{
Studies of Water Arsenic and Boron Pollutants and Algae Phytoremediation in Three Springs, Iran
}

\author{
Noori Mitra ${ }^{1, *}$, Zakeri Rezvan', Mazaheri Seyed Ahmad ${ }^{3}$, Mahmudy Gharaie Mohamad Hosein ${ }^{3}$ \\ ${ }^{1}$ Department of Biology, Faculty of Science, Arak University, Arak, 38156-8-8349, Iran \\ ${ }^{2}$ Department of Geology, Ferdowsi University of Mashhad, Iran \\ ${ }^{3}$ Department of Geology, Faculty of Sciencet, Ferdowsi University of Mashhad, Iran
}

\begin{abstract}
Today drinking water quality, water pollutant and cleaning water are important topics in applied hydrology. Algae play an important role in controlling metal concentration in lakes and oceans. Their ability to absorption metals and taking up toxic elements from the environment has been recognized for many years. The study is examination of the possible extent of Arsenic and Boron algae phytoremediation in three springs from Sang-E-Noghreh area, Iran, by calculating bio-concentration and bio-accumulation factors in them. Water samples from the sites were separately collected for microscopy, ICP/MS analyzing and graphitic oven. Algae were identified and counted using available equipment and references. Data analyzed and bio-concentration (BCF) and bio-accumulation factors (BAF) were calculated for Boron and Arsenic. Results showed four algal divisions (Chlorophyta, Cyanophyta, Euglenophyta and Heterokontophyta) in all of sample sites waters with the exception of Gargab that lacked Euglenophyta. Boron and Arsenic BAF were higher than 10 in all three sites. It is believed that algal flora of three springs have absorbed and accumulated these elements from their environment into their bodies. Then these algae can be hyper-phytoremediator and their presence in water reduced water Arsenic and Boron pollutant.
\end{abstract}

Keywords Biological treatment, Algae, Phytoremidiation, Arsenic, Boron, Iran

\section{Introduction}

Many environmental pollutants move through food chains and accumulate at sizeable levels in the tissues of animals and man[1,2]. A high environmental persistence and high lipophilicity chemicals should be thoroughly investigated for their potential toxicity through bioconcentration and bioaccumulation, both measured for long periods of exposure. Phytoremediation is one new approach that offers more ecological benefits and a cost efficient alternative. The plant used in the phytoremediation technique must have a considerable capacity of metal absorption, its accumulation and strength to decreasethe treatment time[3]. The chemical compounds bioconcentration and bioaccumulation in aquatic and terrestrial organisms represent important criteria for ecotoxicological evaluation and hazard assessment[4,5]. Recent developments in environmental research have revealed that many living organisms can accumulate certain toxicants to body concentrations much higher than present in their environments[6].

Water pollution is one of the human problems in recent century. It is known as increasing some element

* Corresponding author:

m-noori@araku.ac.ir (Mitra Noori)

Published online at http://journal.sapub.org/ije

Copyright (C) 2012 Scientific \& Academic Publishing. All Rights Reserved concentration having poisonous potential from the standards, can produce irreparable environmental effects[7]. A variety of both biotic and abiotic factors have been implicated in determining the boundaries of species distributions and water qualification. Biotic factors important to segregation include resources, predators and aquatic macrophytes. Abiotic factors such as dissolved oxygen, temperature and light can also influence the distribution of aquatic species[8,9]. So, studying biological and physico-chemical factors of water is necessary for finding suitable and economic ways for water quality improvement. Biological filtration of water is one of the standard and economical methods in comprising with other methods. Some living organisms such as algae are able to reduction or removing toxic elements by absorption from their environment. This method is called phytoremediation[10]. Phytoremediation is considered the remediation technique that generates the lowest negative environmental impact on the remediation sites and can be applied into newly developed urban areas because of its high public acceptance and its function as an aesthetical pleasure[11].

Algae are a group of living organisms that play an important role in controlling metal concentration in lakes and oceans[12,13] and the density and absorption of pollutants such as heavy metals in their environment[10]. The ability of algae to absorb metals has been recognized for many years. Algae possess the ability to take up toxic elements from the 
environment, resulting in higher concentrations than those in the surrounding water[11,14]. Bioaccumulation studies reveal the accumulation of the contaminant in the organism via uptake of food or water containing the contaminant[15].

Arsenic have been classified as group I carcinogens based on human epidemiological data[16]. Some aquatic macrophytic species (Eichhornia crassipes, Lemna gibba, Lemna minor, Spirodela polyrhiza, Ipomoea aquatic, Azolla caroliniana, Azolla filiculoides, Azolla pinnata, Pistia stratiotes, Hydrilla verticillata and Lepidium sativum) have been reported to accumulate high level of arsenic from contaminated water. Their arsenic uptake ability, mechanisms and their potential in phytoremediation technology have been studied and evaluated[9].

Boron contamination is a serious environmental problem affecting both ecosystems and human activities[17]. Exposure to large amounts of boron over short periods of time can affect the stomach, intestines, liver, kidney, and brain and can eventually lead to death[18]. In order determining the environmental fate of released chemicals from different pollutant sources, to determine their bioconcentration in aquatic species is essential. Bio-concentration factor (BCF) of a chemical compound is defined as the ratio between the concentration of that chemical in an organism (Corg) and the concentration of the chemical compounds in the aqueous environment $(\mathrm{Cm})[2,19-26]$. The calculation of BCFs can be based on the wet weight $(\mathrm{BCFw})$ or on the lipid content $(\mathrm{BCFl})$, of the aquatic organism or its tissue. BCFs are usually determined for various species of fish, but other aquatic organisms can be used, such as algae or mussels. Aquatic organisms can accumulate chemical compounds both directly from the environment (via skin or respiratory surface) and indirectly (by collecting and concentrating a chemical compound from food). This process is called bioaccumulation, and is measured with the bioaccumulation factor (BAF) which is defined as the ratio of the concentration of a chemical accumulated inside an organism (Corg) to the concentration in the surrounding environment $(\mathrm{Cm})$ $[1,2,4,16]$. The bioaccumulation level depends on the nature of the chemical compound, species, duration of exposure, concentration in water and its accumulation level in food[27]. BAF was categorized as: $<1$ excluder, 1-10 accumulators, $>10$ hyper accumulators[28,29]. Shamsuddoha et al. (2006) in their studies on growing algae in rice fields showed that algae can hyper accumulate as from water[14]. Also a rice variety receiving arsenic-contaminated irrigation water ranging from 0 to $2.0 \mathrm{mg}$ as $/ \mathrm{L}$, and grown with and without algae, showed that the presence of algae in the growth medium reduces as accumulation in rice. The pot experiment showed that algae could reduce accumulation of arsenic in rice plants by as much as $71 \%$. Algal growth was also found to depress arsenic accumulation in soil[15].

The present study is an attempt to examine the possible extent of phytoremediation Arsenic and Boron by algae in three spring waters from Sang-E-Noghreh area (Khorasan-eRazavi), Iran by calculating bio-concentration and bio-accumulation factors in algae.

\section{Materials and Methods}

\subsection{Study Site}

Experiments were carried out in Sang-E-Noghreh Village in $115 \mathrm{Km}$ to South-East of Mashhad-Khorasan Razavi, Iran and $40 \mathrm{~km}$ to South of Fariman. The area is located on long. $35^{\circ} 26^{\prime}$ to $35^{\circ} 30^{\prime} \mathrm{N}$ and lat. $59^{\circ} 50^{\prime}$ to $59^{\circ} 52^{\prime} \mathrm{E}$ with 1077 hectare sureface area, $1600-2830 \mathrm{~m}$ altitude from sea sureface. For studies of algal flora and Arsenic and Boron algae phytoremediation with calculating bio-concentration and bio-accumulation factors in Sang-E-Noghreh, three springs (Arrehe kamar $=\mathrm{A} 1$, Zireh Ghaleh $=\mathrm{A} 2$ and Gargaab $=\mathrm{A} 3$ ) were selected (Figure 1).

\subsection{Sampling and Analyses}

In March, 2010 water samples from the sites were collected for ICP/MS analyzing after measuring some water physical factors such as $\mathrm{pH}$ and temperature using HDPE vials. Each water sample was filtered using $0.45 \mu$ micro filter and then poured in the labeled vial. Then samples $\mathrm{pH}$ was regulated by adding nitric acid and stored at $4^{\circ} \mathrm{C}$ until sending to the Canadian Acme Laboratory. Also for algal flora studies three groups of algal samples were collected.

First group of algal samples were collected for studying density without any fixation, Second group was fixed for identification using fixative $(0.1 \mathrm{M}$ Sodium Cacodylate and $\% 6$ Glutaraldehyde) and third group were collected in sterile vial for element concentration measurement. All of samples were put into the aluminum cover and kept in $4^{\circ} \mathrm{C}$. Then, samples were transferred to the laboratory. Algae of first and second group samples were identified using light microscopy and available references[30-34]. Counting of samples was undertaken based on Lobban et al (1998)[35] method. Third group samples were dried using $80^{\circ} \mathrm{C}$ oven for 24 hours. After sample digestion and filtration, boron and arsenic concentration was measured using Shimaduz.AA670 graphitic oven.

\subsection{Data Analysis}

Data were analyzed using the $\mathrm{EXCEL}_{2007}$ software. Figure 2 show four identified algal division concentrations in three springs of Sang-E- Noghreh area in winter. Also bio- concentration $(\mathrm{BCF})$ and bio-accumulation factors $(\mathrm{BAF})$ were calculated for Boron and Arsenic elements in three examined spring waters. Results have been shown in Table 1.

\section{Results}

Results of algal flora studies showed existing four algal divisions (Chlorophyta, Cyanophyta, Euglenophyta and Heterokontophyta) in all of sample sites waters with the exception of $\mathrm{A}_{3}$ site that lacked Euglenophyta. Table 1 and Figure 2 show the divisions concentrations in three springs (Arrehe kamar $=A_{1}$, Zireh Ghaleh $=A_{2}$ and Gargaab $=A_{3}$ ) of Sang-E- Noghreh area in winter. The most algal genera 
variation was observed in $A_{3}$. $A_{1}$ had the highest level of family and order numbers (Table 1 ). $A_{1}$ site showed the highest Chlorophyta and Cyanophyta density $\left(\mathrm{mm}^{3}\right)$, while, Heterokontophyta had the highest concentration in $\mathrm{A}_{3}$ site (Figure 1). Also Arsenic and Boron concentrations in water and algae samples from these springs (BFCs) and their bio-accumulation factors (BAFs) have been shown in Table 1. As the Table shows algal Arsenic concentration (ppb) of $A_{1}$ site is higher than two others, whiles, $A_{2}$ had the most algae Boron concentration (ppb). $A_{1}$ site showed the highest level of Arsenic and Boron bio-accumulation factors (BAFs) (Table 1).

\section{Discussion and Conclusions}

Based on our results it is believed that absences (in A3) or low density presences (in $A_{2}$ and $A_{3}$ ) of Euglenophyta in all three studies sample sites in winter depended on low water temperature(Figure 1). As Shayestehfar et al (2010) showed temperature regulates the density and diversity of zooplankton in freshwater. Their data showed that maximum zooplankton density occurred in $26.5^{\circ} \mathrm{C}$ to $28.1^{\circ} \mathrm{C}$ air and water temperature[36]. Also Khodaparast(1998) studies showed the most frequency of Euglenophyta was observed in increasing water temperature and entering organic compounds into the water[37]. Chlorophyta density was nearly equal in all three sample sites. But it was more in A1 comparing to $\mathrm{A} 2$ and $\mathrm{A} 3$ and Cyanophyta density was much more in A1 too. Our data comparison with WHO (World Health Organization) standard showed water Arsenic concentration is higher than drinking water standard limit in A3 site, but $\mathrm{A} 1$ and $\mathrm{A} 2$ are in standard limit. Boron in $\mathrm{A} 2$ and $\mathrm{A} 3$ water samples was higher than drinking water standard limit, while A1 was in standard limit[38] (Table 1). Also bio-accumulation factors (BAFs) for these elements were higher than 10. Therefore Chlorophyta and Cyanophyta are hyper-absorbent and hyper-accumulator for Arsenic and Boron[28]. Comparison of Arsenic and Boron BAFs in three studied sites showed the highest level in A1 for both elements(Table 1). It is believed that Chlorophyta and Cyanophyta have absorbed and accumulated these elements from their environment into their bodies. Then these algae can be hyper-phytoremediator and their presence in water reduced water Arsenic and Boron pollutant. In A3, by the reason Heterokontophyta high density and low density of Cyanophyta, its Arsenic and Boron water is more than two other sites. Based on these results it can be concluded that existing pectocellulose compounds in Chlorophyta and silica in Heterokontophyta cell walls have prevented of Arsenic and Boron high level absorption from their environment. Peptidoglycan cell wall presence in Cyanophyta cell wall and absence of silica and pectocellulose may be caused more absorption of these two elements from water in comparison with Chlorophyta and Heterokontophyta. Studies of physic-chemical effects of water especially heavy metals concentrations on algae density in three springs of Sang-E-Noghreh area, Iran in winter showed that positive correlations between Arsenic concentration and Heterokontophyta density[10]. Phytoremediation of waters by aquatic organisms such as algae has been recently explored for the removal of organic pollutants possessing endocrine disrupting capacity (39). Also Sjahrul (2012) reported using marine phytoplanktons (Tetracelmis chuii and Chaetoceros calcitrans) as phytoremediators (40). Sekabirak et al (2010) studies showed that algae have the potential to accumulate $\mathrm{Pb}, \mathrm{Cd}, \mathrm{Cu}$, and $\mathrm{Zn}$. Algae can thus be used in bio-monitoring of heavy metal pollution in urban stream water since it can be used in quantification of pollutants. Concentrations of heavy metals in algal biomass reflect metal load in the stream water. Algae can therefore be used in the phytoextraction process of heavy metals in aquatic urban stream water and wastewater effluents (41). Imamul Huq et al (2007) showed that Navicula (a Heterokontophyta genus) was able to Arsenic bio-absorption from its environment) [15]. According to our results and above cases pure cultivation of each algae genus from Chlorophyta, Cyanophyta and Heterokontophyta in different pollutant media is separately suggested. Then, it can be exactly help us for a clear conclusion about accumulated or remediated algae taxa.

Table 1. Results of water samples algal studies and their analysis using microscopy, ICP/MS and graphitic oven methods from three springs in Sang-E-Noghreh area, Iran (Arrehe kamar $=\mathrm{A}_{1}$, Zireh Ghaleh $=\mathrm{A}_{2}$ and Gargaab $=\mathrm{A}_{3}$ ) and their Arsenic and Boron bio-concentration $(\mathrm{BCF})$ and bio-accumulation factors (BAF) in winter

\begin{tabular}{cccc}
\hline Factors & \multicolumn{3}{c}{ Sample sites (Springs) } \\
\cline { 2 - 4 } & ArrehKamar (A1) & Zireh Ghaleh (A2) & Gargaab (A3) \\
\hline Algae Arsenic concentration (ABCFA) ppb & 75086 & 18386 & 16198 \\
Water Arsenic concentration (WBCFA) ppb & 6.5 & 2.3 & 22.70 \\
BAF of Arsenic (ppb) & 11551.69 & 7993.91 & 713.57 \\
Algae Boron concentration (ABCFB) ppb & 165210 & 267370 & 191200 \\
Water Boron concentration (WBCFB) ppb & 211 & 1194 & 1260 \\
BAF of Boron (ppb) & 782.99 & 223.93 & 151.75 \\
Chlorophyta density in $\mathrm{mm}^{3}$ (in winter) & 381 & 300 & 307 \\
Cyanophyta density in $\mathrm{mm}^{3}$ (in Winter) & 5347 & 1753 & 1824 \\
Euglenophyta density in mm (in Winter) $^{3}$ (in & 19 & 6 & 0 \\
Heterokontophyta density in mm (in Winter) & 106 & 33 & 427 \\
Algal orders numbers & 9 & 5 & 5 \\
Algal families number & 13 & 6 & 9 \\
Algal genera numbers & 18 & 7 & 20 \\
\hline
\end{tabular}




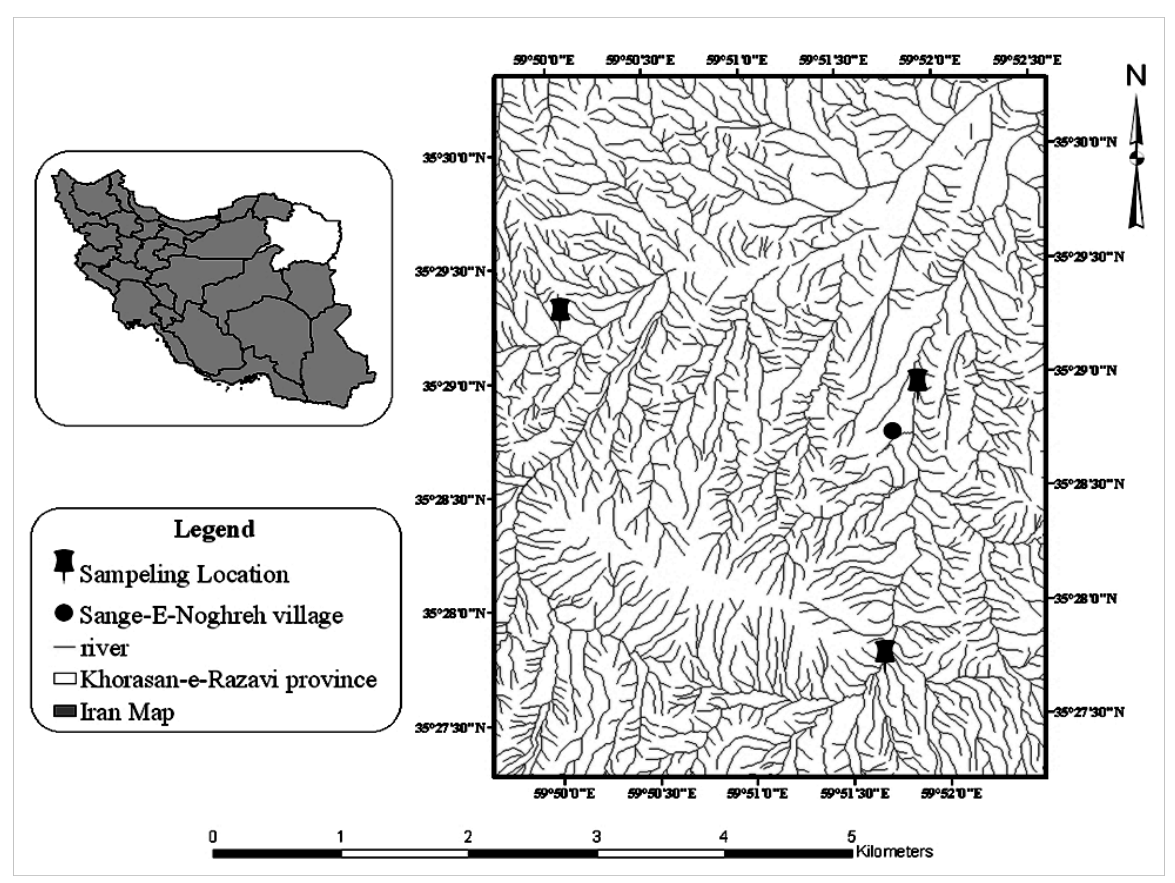

Figure 1. Water and algae sampling sites location in Sang-E- Noghreh area, Iran

口Total Chlorophyta Density

口Total Cyanophyta Density

-Total Euglenophyta Density

- Total Heterokonteophyta Density

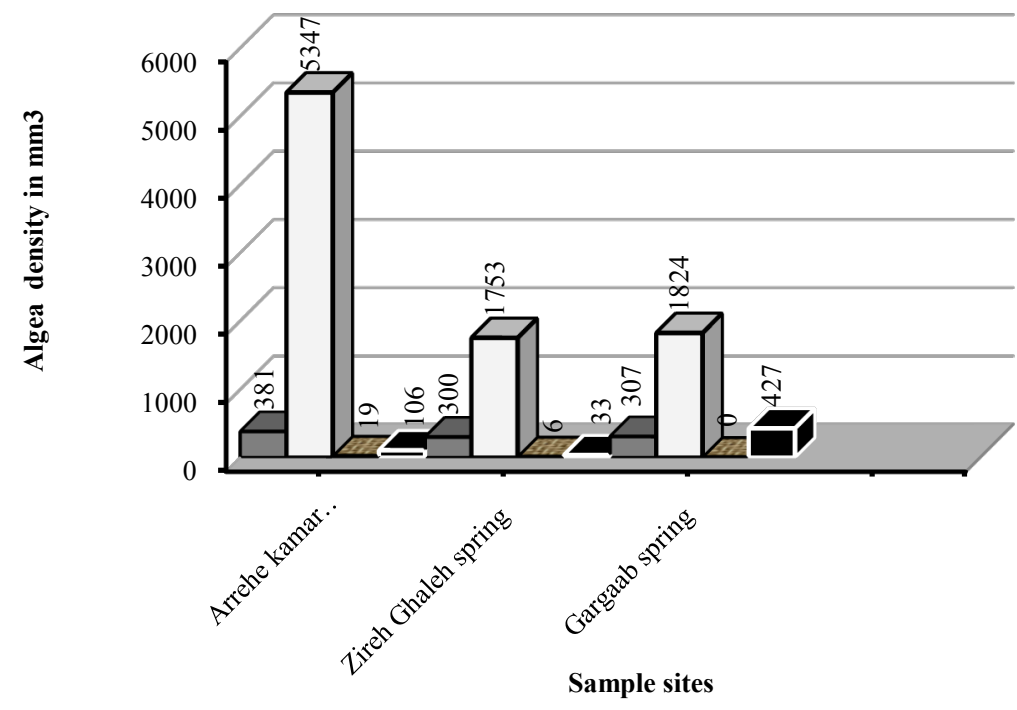

Figure 2. Four identified algal division concentrations in three springs of Sang-E- Noghreh area, Iran in winter

\section{ACKNOWLEDGMENTS}

The authors would like to thank of M. Zakeri for her helps in collecting and determination of some samples.

\section{REFERENCES}

[1] FRANKE C, STUDINGER G, BERGER G, BOHLING S, BRUCKMANN U, COHORS-FRESENBORG D \&
JOHNCKE U. 1994. The assessment of bioaccumulation, Chemosphere, 29: 1501-1514.

[2] FEIJTEL T, KLOEPPER-SAMS P, DEN HAAN K, VAN EGMOND R, COMBEE M, HEUSEL R, WIERICH P, TEN BERGE W, GARD A, WOLF W \& NIESSEN H. 1997. Integration of bioaccumulation in an environmental risk assessment, Chemosphere, 34: 2337-2350.

[3] MUDGAL V, MADAAN N \& MUDGAL A. 2010. Heavy metals in plants: phytoremediation: Plants used to remediate heavy metal pollution, Agric. Biol. J. N. Am., 1 (1): 40-46.

[4] MACKAY D \& FASTER A. 2000. Bioaccumulation of persistent organic chemicals: mechanism and models, Environ, Pollut., 110: 375-391. 
[5] VOUTSAS E, MAGOULAS K \& TASSIOS D. 2002. Prediction of the bioaccumulation of persistent organic pollutants in aquatic food webs, Chemosphere, 48: 645-651.

[6] KORD B; MATAJI A \& Babaie S. 2010. Pine (Pinus Eldarica Medw.) needles as indicator for heavy metals pollution, Int. J. Environ. Sci. Tech., 7 (1): 79-84.

[7] ZAKERI R, MAZAHERI S A, MAHMUDY GHARAIIE M H, Noori M and Sayareh A. 2011a. Geology effect of Sang-E-Noghreh area (South of Fariman) on the water resource pollution to arsenic and boron, 15th Geological Society of Iran Congress, 14-15 Desember 2011, Tehran-Iran.

[8] BOZKURT A \& GUYEN S. E. 2009. Zooplankton composition and distribution in vegetated and unvegetated area of three reservoirs in Hatay, Turkey, Journal of Animal and Veterinary Advances, 8 (5): 984-994.

[9] AZIZUR RAHMAN M \& HASEGAWA H. 2011. Aquatic arsenic: Phytoremediation using floating macrophytes. Chemosphere, 83 (5): 633-646.

[10] ZAKERI R, NOORI M, ZAKERI M, MAZAHERI S A, MAHMUDY GHARAIIE M H. 2011b. Studies of the physico-chemical effects of water especially heavy metals concentration on algae density in three springs of Sang-E-Noghreh area (fariman) in winter, 1th National Conferences of Phycology of Iran, Shahid Beheshti University, 14-15 September 2011, Tehran-Iran.

[11] CHANG P, KIM J Y \& KIM K W. 2005. Concentrations of arsenic and heavy metals in vegetation at two abandoned mine tailings in South Korea, Environmental Geochemistry and Health, 27: 109-119.

[12] SIGG L. 1985. Metal transfer mechanisms in lakes; role of settling particles, In: Chemical Processes in Lakes, Stumm, W. (ed.), Wiley Interscience, New York, pp. 283-310.

[13] SIGG L. 1987.Surface chemical aspects of the distribution and fate of metal ions in lakes. In: Aquatic Surface Chemistry, Stumm, W. (ed.), Wiley Inter science, New York. P. 319-348.

[14] SHAMSUDDOHA A S M, Bulbul, A \& IMAMUL HUQ S M. 2006. Accumulation of arsenic in green algae and its subsequent transfer to the soil-plant system, Bangladesh J. Microbiol., 22 (2): 148-151.

[15] IMAMUL HUQ S M, BINTE ABDULLAH M \& JOARDAR J C. 2007. Bioremediation of arsenic toxicity by algae in rice culture, Land Contamination \& Reclamation, 15 (3): 327-334.

[16] MEYLAN W M, HOWARD P H, BOETHLING R S, ARONSON D, PRINTUP H \& GOUCHIE S. 1999. Improved method for estimating bioconcentration/ bioaccumulation factor from octanol/water partition coefficient, Environ., Toxicol., Chem., 18: 664-672.

[17] KAYAMA Y. 2010. Treatments of Severely Boron-Contaminated Soils for Phytorestoration, Phytorestoration, Spring, pp: 1-17.

[18] HUGHES M F. 2002. Arsenic toxicity and potential mechanisms of action. Toxicol., Lett., 133 (1): 1-16 .

[19] ATSDR (Agency for Toxic Substances and Disease Registry). 2010. Toxicological profile for boron. Atlanta, GA: U.S. Department of Health and Human Services, Public
[20] IVANCIUC O. 2003. Aquatic toxicity prediction for polar and nonpolar narcotic pollutants with support vector machines, Internet Electron, J. Mol., Des., 2: 195-208.

[21] HANSCH C \& Leo A. 1995. Exploring QSAR. Fundamentals and applications in chemistry and biology, American Chemical Society, Washington, DC, pp: 580.

[22] GRAMATICA P \& Papa E. 2003. QSAR modeling of bioconcentration factor by theoretical molecular descriptors, QSAR Comb., Sci., 22: 374-385.

[23] DEVILLERS J, DOMINE D, BINTEIN S \& KARCHER W. 1998. Fish bioconcentration modeling with $\log$ P, Toxicol., Methods, 8: 1-10.

[24] DEARDEN J C \& SHINNAWEI N M. 2004. Improved prediction of fish bioconcentration factor of hydrophobic chemicals, SAR QSAR Environ. Res., 15: 449-455.

[25] HU H, XU F, LI B, CAO J, DAWSON R \& TAO S. 2005. Prediction of the bioconcentration factor of PCBs in fish using the molecular connectivity index and fragment constant models, Water Environ, Res., 77: 136-150.

[26] DAVIES R P \& DONAS A J. 1984. The prediction of bioconcentration in fish, Water Res., 18: 1253-1262.

[27] IVANCIUC T, IVANCIUC O \& KLEIN D J. 2006. Modeling the bioconcentration factors and bioaccumulation factors of polychlorinated biphenyls with posetic quantitative super structure/activity relationships (QSSAR), Molecular Diversity, Springer, 10: 133-145.

[28] BAKER A J M. 1981. Accumulators and excluders- strategies in tha response of plants to heavy metals, J. Plant Nutri., 3 (1-4): 643-654.

[29] MA L Q., KOMAR K M, TU. C, ZHANG W, CAI Y \& KENELLY ED. 2001. A fern that hyper-accumulates arsenic, Nature, 409: 579-582.

[30] RAHIMIAN H. 1978. Phycology, Iran Meli University Publication, No. 152, Tehran.

[31] MOHAMEDI H. 1984. A Beginner's Guide to Freshwater Algae (Belcher H. and Swale E.) Institute of Technical Fishery Publication, Ofset Sahami Am Iran Company Print, First Edition.

[32] LEE R E. 1999. Phycology, Cambridge University Press, 3th Edition, Cambridge.

[33] BROIDE J \& LEWIEE E. 2007. The Systemetics Association Special Volume Series 75 Unravelling the algae the past, present,and future of algal systematic, CRC Press is an important of Taylor \& francis Group, an Information business, $376 \mathrm{p}$.

[34] NOORI M \& AHMADI A. 2007. Thallophytes, Sabike Publications, Iran.

[35] LOBBAN S C, CHAPMAN J D \& Kremer P D B. 1988. Experimental Phycology, A Laboratory Manual, Cambridge University Press, UK.

[36] SHAYESTEHFAR A, NOORI M \& SHIRAZI F. 2010. Environmental factor effects on the seasonally changes of zooplankton density in Parishan Lake (Khajoo Spring site), Iran, Asian Journal of Experimental Biological Sciences, 1 (4): 840-844. 
[37] KHODAPARAST SH. 1998. Final report of Talab-e-Anzali hydrology and hydrobiology project from 1992 to 1996, Fishery Research Center of Gilan Province.

[38] WHO. World Health Organization, Chemical fact sheets, Guidelines for Drinking Water Quality. First Addendum To Third Edition, 2008: 296-405.

[39] GATTUllo CE, BAHRS H, STEINBERG CE \& LOFFREDO E. 2012. Removal of bisphenol A by the freshwater green alga Monoraphidium braunii and the role of natural organic matter. Sci Total Environ, 416: 501-506.

[40] SJAHRUL, M. 2012. Phytoremediation of $\mathrm{Cd} 2+$ by Marine Phytoplanktons, Tetracelmis chuii and Chaetoceros calcitrans. International Journal of Chemistry, 4 (1): 69-74.

[41] SEKABIRA K, ORYEM ORIGA H, BASAMBA TA, MUTUMBA G \& KAKUDIDI E. 2010. International Journal of Environment Science and Technology, 8 (1): 115-128. 